\title{
THE ANALYSIS OF CONSUMERS' PURCHASING FACTORS ON BOGA SERVICE START-UP
}

\author{
Finolda, Metta Padmalia \\ Universitas Ciputra, Surabaya
}

\begin{abstract}
This study aims to analyze the factors of consumer behavior in purchasing Empal Catering Bibik. The factors examined in this study are cultural factors, social factors, personal factors and psychological factors. The population in this study were consumers of Empal Catering Bibik. The sample size of 40 respondents. The research samples were collected using non-probability sampling methods and purposive sampling techniques. The research data was taken by using questionnaires which were distributed to respondents. Data analysis using the second order confirmatory analysis factor analysis. The results of data processing shows that consumer behavior factors in purchasing consumer food service start-ups are personal factors and psychological factors.
\end{abstract}

Keywords: consumer behavior, cultural factors, social factors, personal factors, psychological factors, factor analysis

\section{INTRODUCTION}

The value offered in the catering business is to provide convenience to consumers who need food at school, college, work. In addition, this business also aims to help housewives in preparing food for family members when busy. The food industry is one of the promising businesses today. Food Industry Data shows 8.67\% growth in Quarter II 2018 in the food business. This figure exceeds the national economic growth of 5.27\% (Ministry of Industry). The food industry is growing well because this industry has a large demand. One type of food industry that has attracted entrepreneurs to make their business is a catering business. More and more start-up businesses in the catering sector. Consumers tend to constantly move to buy catering products (Wibowo \& Bacthiar, 2018). However, in the end, consumers will buy the product that best suits their identity (Solomon, 2018, p. 129).

*Corresponding Author. e-mail: finolda16@gmail.com
Purchases that consumers make affect sales. There are many factors that encourage consumers to make product purchases. Sangadji \& Sopiah (2013, p. 40) says that purchases that consumers make depend on their own behavior. Consumer behavior results from complex interactions of cultural, social, personal, and psychological factors (Kotler \& Armstrong, 2018, p. 173; Kotler \& Keller, 2016, p. 180). Different consumer behavior affects the reaction to a product. This is because consumer behavior influences how to search for product information and evaluate the product (Solomon, 2018, p. 58).

Even though consumer behavior cannot be controlled, the behavior plays an important role in purchasing a product. Therefore, consumer behavior is important to be taken into account (Kotler \& Armstrong, 2018, p. 159). Based on the theory of consumer behavior above, this study was conducted to analyze the factors of consumer behavior in purchasing food service start-up products. This study is entitled "Analysis of Consumer Purchasing Factors at Food Service Start-Ups". 
Finolda, Metta Padmalia / The Analysis of Consumers' Purchasing Factors on Boga Service Start-Up / JEE, Vol. 8, No. 1, March 2019, pp. 25-32

Consumer behavior is the process when Personals or groups choose, buy, use, or dispose of a product, service, idea, or experience to meet their needs and desires (Solomon, 2018, p. 51). Consumer behavior is the result of interactions between cultural factors, social factors, personal factors and psychological factors (Kotler \& Armstrong, 2018, p. 173). Consumers interact with these factors in the surrounding environment. The interaction raises awareness, behavior, thoughts and feelings to make purchases consisting of kulutral, social, personal, and psychological factors. (Peter \& Olson, 2009, p. 6).

Cultural factors are factors that are related to consumer values and behavior. This factor was built since they were small through norms, traditions, religion, and others. Social factors shape consumer behavior through interactions with people around. Personal factors shape consumer behavior through the needs of each Personal. For example, someone buys a product that they think suits him. Psychological factors combine with awareness about needs and wants. Psychological factors generate thinking and encourage consumer behavior to buy products (Kotler \& Keller, 2016, p. 187).

Consumer behavior as the dependent variable is described by cultural factors, social factors, personal factors, and psychological factors. Cultural factors consist of culture, subculture, and social class. The third factor, personal factors, consists of age \& stage of life, work \& economic circumstances, personality $\&$ life concepts, and lifestyle. The last factor that shapes consumer behavior is psychological factors. This factor consists of motivation, perception, learning, emotions, and memory.

The population in this study is Caterpillar Empal Catering consumers, that is, one of the start-up businesses that Ciputra University stu- dents in Management major have. The sample in this study was taken using a purposive nonprobability sampling technique. The sample size is determined based on the Roscoe Formulation in Indrawan \& Yaniawati (2017, p. 103), that is, the sample size is determined from $10 \mathrm{x}$ the number of variables. The results of the sample calculation are $10 \times 4=40$ people. This sample size is considered to meet the feasibility of the number of samples in the study. Ghozali \& Latan (2015, p. 51) argues that research using PLS can involve a minimum sample of $30-100$ respondents.

This study uses a quantitative approach. Data obtained through a questionnaire distributed to 40 respondents. The questionnaire was assessed using a Likert Scale with the following conditions 1 Strongly Disagree (STS), 2 Disagree (TS), 3 Fairly Agree (CS), 4 Agree (S), and 5 Strongly Agree (SS). Data analysis was performed using factor analysis. Factor analysis in this study is confirmatory factor analysis using the SMARTPLS 3.0 application. This study uses a second order confirmatory factor analysis, which is the first measurement carried out by analyzing the latent construct of the indicator. The second measurement is done by analyzing latent constructs to the constructs of its dimensions (Ghozali \& Latan, 2015, p. 109). First order construct is run by testing the construct to the indicator. This measurement is used to measure validity and reliability. The measurement results are evaluated through convergent and discriminant validity of the indicators forming latent constructs and composite reliability and Cronbach with the provisions of the value: Loading factor $>0.7$, Average Variance Extracted (AVE) $>0.50$, Cross loading $>0.70$, Cronbach's alpha $>0.70$, Composite reliability $>0.70$. Testing is done through two levels, namely the analysis of the latent con- 
structs of the dimensions to the indicators and analysis of the latent constructs to the dimensions of the constructs. The second order construct looks at the loading factor path coefficient value.

\section{RESULTS}

Respondents in this study were dominated by women aged 21-25 years, studying, not married, with an average consumption expenditure of 1-3 million/month (Appendix 1). The characteristics of each consumer takes a role in shaping consumer behavior in catering purchases. Most of the consumers of food service start-up businesses are women. This relates to a person's personality, which is sexually influencing the attitude towards a product. Women's responses to catering products are better than men's responses. Personality is a characteristic that distinguishes women from men where the first is responsive to the choice of products and brands (Sunarto, 2018).

Age can form the desires and needs of different people in consuming a food (Suprayitno, et al., 2015). People will change the goods and services they buy as life cycle changes. Increasing age causes changing needs (Sunarto, 2018). The life cycle of humans is children, adolescents, adults, work, marriage and so on. Most of the consumers of food service start-up businesses are still 21-25 years old and they are not married. They have different catering needs than married people.

Work affects the cost they spend to buy goods and services (Sunarto, 2018). The work someone has can affect consumption patterns because it is related to income. Meanwhile, income affects the ability to consume a product (Suprayitno, et al., 2015). Characteristics of respondents in this study are those who have not worked and have an average monthly consumption expenditure of $\mathrm{Rp} 1-3$ million.

\section{First Order Construct}

The first stage of First Order is to measure validity (Table 1 ). The calculation is as follows. The loading factor value $<0.7$ produces X1.1 with a value of 0.535 , X1.2 with a value of $0.609, \mathrm{X} 2.1$ with a value of $0.651, \mathrm{X} 2.2$ with a value of $0.134, \mathrm{X} 3.4$ with a value of 0.486 , X4.4 with a value of 0.657 . A factor loading value $<0.7$ indicates that the indicator cannot explain more than half the measured variable. This statement can be explained that the loading factor of 0.7 squared is equal to 0.5 . This means that the indicator can explain at least half of the variables if the indicator has a loading factor $>0.7$ (Hair et al., 2014, p. 618). As a result, indicators with a loading factor $<0.7$ must be eliminated because they do not represent at least half of the latent variables. AVE is the average square of the loading factor (Hair et al., 2014, p. 619). AVE which is $<0.5$ indicates that the variable cannot be explained by a combination of indicators. AVE variable $\mathrm{X} 10.411$ and X2 0.318 gives the meaning that

Table 1 The Results of Convergent Validity Test

\begin{tabular}{lccc}
\hline Variabel & Indikator Loading Factor & AVE \\
\hline Cultural Factor (X1) & X1.1 & $\mathbf{0 . 5 3 5}$ & \\
& X1.2 & $\mathbf{0 . 6 0 9}$ & $\mathbf{0 . 4 1 1}$ \\
& X1.3 & 0.760 & \\
\hline Social Factor (X2) & X2.1 & $\mathbf{0 . 6 5 1}$ & \\
& X2.2 & $\mathbf{0 . 1 3 4}$ & $\mathbf{0 . 3 1 8}$ \\
& X2.3 & 0.716 & \\
\hline Personal Factor (X3) & X3.1 & 0.844 & \\
& X3.2 & 0.792 & 0.535 \\
& X3.3 & 0.752 & \\
& X3.4 & 0.486 & \\
\hline Psychological Factor (X4) & X4.1 & 0.793 & \\
& X4.2 & 0.813 & \\
& X4.3 & 0.876 & 0.641 \\
& X4.4 & 0.657 & \\
& X4.5 & 0.845 & \\
\hline
\end{tabular}


Finolda, Metta Padmalia / The Analysis of Consumers' Purchasing Factors on Boga Service Start-Up / JEE, Vol. 8, No. 1, March 2019, pp. 25-32

the variable $\mathrm{X} 1$ correlates with the indicator with a value of $41.1 \%$. Meanwhile, the remaining $58.9 \%$ is a mistake. Meanwhile, variable X2 is correlated by the indicator of $31.8 \%$ and the remaining $68.2 \%$ is error.

The second stage is the reliability test by looking at the value of cronbach's alpha and composite reliability (Table 2). Table 2 explains that some variables do not meet the requirements $>0.7$, that is, X1 with cronbach's alpha value 0.289 and composite reliability $0.672 \mathrm{X} 2$ with cronbach's alpha value 0.046 and composite reliability 0.524 .

Table 2 Reliability Test Results

\begin{tabular}{lcc}
\hline Composite Reliability & $\begin{array}{c}\text { Cronbach's } \\
\text { Alpha }\end{array}$ & $\begin{array}{c}\text { Composite } \\
\text { Reliability }\end{array}$ \\
\hline Cultural Factor & $\mathbf{0 . 2 8 9}$ & $\mathbf{0 . 6 7 2}$ \\
Social Factor & $\mathbf{0 . 0 4 6}$ & $\mathbf{0 . 5 2 4}$ \\
Personal Factor & 0.693 & 0.816 \\
Psychological Factor & 0.857 & 0.898 \\
\hline
\end{tabular}

X3 with Cronbach's alpha value 0,693 and Composite reliability 0,816 and $\mathrm{X} 4$ with Cronbach's alpha value 0,857 and Composite reliability 0,898 otherwise reliable. This proves the accuracy and accuracy of the X3 and X4 indicators in measuring the variables. Meanwhile, indicators X1 and X2 do not have accuracy and accuracy in measuring the variables.

Based on the validity and reliability test, variable X1 with indicators X1.1, X1.2, variable X2 with indicators X2.1, X2.2, variable $\mathrm{X} 3$ with indicator $\mathrm{X} 3.4$, and variable $\mathrm{X} 4$ with indicator X4.4 are declared ineligible validity and reliability. As a result, these variables must be eliminated (Table 3 ).

There is a change in the shape of the analysis model before and after elimination. The figure after indicator elimination shows that the variables X1 and X2 leave one indicator each. As a result, the variable does not meet the minimum indicator requirements in factor
Table 3 The Results of Discriminant Validity Tests

\begin{tabular}{cccccc}
\hline & \multicolumn{3}{c}{ First Order Construct } & $\begin{array}{c}\text { Second } \\
\text { Order }\end{array}$ \\
\cline { 2 - 6 } Indicator & $\mathrm{X}_{1}$ & $\mathrm{X}_{2}$ & $\mathrm{X}_{3}$ & $\mathrm{X}_{4}$ & $\begin{array}{c}\text { Consumer } \\
\text { Behavior }\end{array}$ \\
\hline $\mathbf{X}_{1.1}$ & 0.535 & 0.211 & 0.273 & 0.226 & 0.328 \\
$\mathbf{X}_{1.2}$ & 0.609 & 0.207 & 0.345 & 0.260 & 0.384 \\
$\mathbf{X}_{1.3}$ & $\mathbf{0 . 7 6 0}$ & -0.007 & 0.567 & 0.380 & 0.515 \\
$\mathbf{X}_{2.1}$ & 0.069 & 0.651 & 0.379 & 0.438 & 0.454 \\
$\mathbf{X}_{2.2}$ & -0.064 & 0.134 & 0.035 & 0.121 & 0.082 \\
$\mathbf{X}_{2.3}$ & 0.194 & $\mathbf{0 . 7 1 6}$ & 0.345 & 0.395 & 0.452 \\
$\mathbf{X}_{3.1}$ & 0.431 & 0.497 & $\mathbf{0 . 8 4 4}$ & 0.581 & 0.733 \\
$\mathbf{X}_{3.2}$ & 0.612 & 0.261 & $\mathbf{0 . 7 9 2}$ & 0.561 & 0.701 \\
$\mathbf{X}_{3.3}$ & 0.365 & 0.423 & $\mathbf{0 . 7 5 2}$ & 0.632 & 0.706 \\
$\mathbf{X}_{3.4}$ & 0.495 & 0.349 & 0.486 & 0.392 & 0.504 \\
$\mathbf{X}_{4.1}$ & 0.484 & 0.447 & 0.582 & $\mathbf{0 . 7 9 3}$ & 0.755 \\
$\mathbf{X}_{4.2}$ & 0.321 & 0.488 & 0.579 & $\mathbf{0 . 8 1 3}$ & 0.741 \\
$\mathbf{X}_{4.3}$ & 0.417 & 0.497 & 0.612 & $\mathbf{0 . 8 7 6}$ & 0.801 \\
$\mathbf{X}_{4.4}$ & 0.306 & 0.401 & 0.486 & 0.647 & 0.614 \\
$\mathbf{X}_{4.5}$ & 0.318 & 0.618 & 0.724 & $\mathbf{0 . 8 4 5}$ & 0.825 \\
\hline
\end{tabular}

analysis, namely three. Thus, the variable must be eliminated (Hair, et al., 2014, p. 608). The Analysis Model after elimination of variables $\mathrm{X} 1$ and $\mathrm{X} 2$ is as follows (Figure 1).

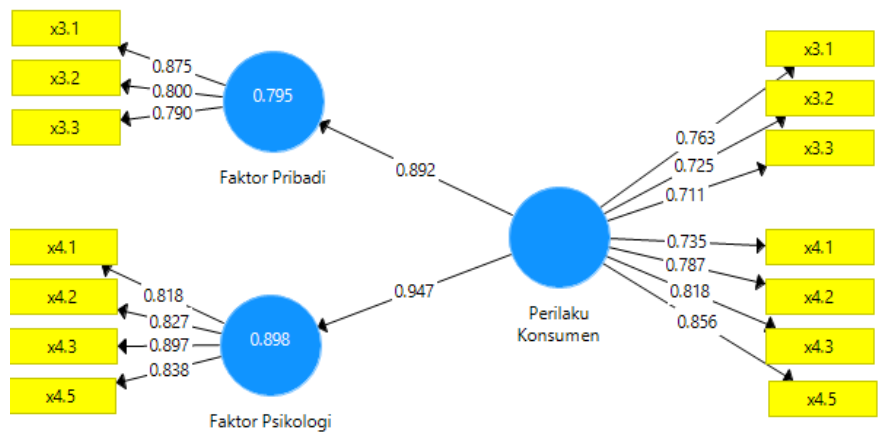

Figure 1 Analysis Model after Variation Elimination

\section{Second Order Construct}

At this stage, measurements (R2) and Tstatistic values are needed to test the significance of the constructs (Ghozali \& Latan, 2013). The value of $\mathrm{R} 2$ shows the value of indicators that can form variables (Table 4).

Variable X3 with 3 indicators has a value of 0.795 . This means that consumer behavior can be formed from personal factors of $79.5 \%$. The remaining $20.5 \%$ is formed from other 
Table $4 \mathrm{R}$ square and t-statistik

\begin{tabular}{|c|c|c|c|}
\hline & R Square & \multicolumn{2}{|c|}{ R Square Adjusted } \\
\hline Personal Factor & 0.795 & \multicolumn{2}{|r|}{0.789} \\
\hline Psychological Factor & 0.898 & \multicolumn{2}{|r|}{0.895} \\
\hline \multicolumn{4}{|r|}{$\begin{array}{c}\text { T Statistics } \\
(|\mathrm{O} / \mathrm{STDEV}|)\end{array}$} \\
\hline \multicolumn{3}{|c|}{ Consumer Behavior $->$ Personal Factors } & 29.220 \\
\hline \multicolumn{3}{|c|}{ Consumer Behavior $->$ Psychological Factors } & 50.348 \\
\hline
\end{tabular}

variables that are outside the studied variables. Variable X4 with 4 indicators has a value of 0.898. This means that consumer behavior can be formed from psychological factors of $89.8 \%$. The remaining $10.2 \%$ is formed from other variables that are outside the studied variables. The t-statistic value of the data processing has exceeded the recommended value of $>1.96$. These results indicate that personal factors and psychological factors are said to be able to shape the behavior of consumers of food service start-up businesses.

\section{DISCUSSION}

Consumer behavior is the result of complex interactions involving cultural factors, social factors, personal factors and psychological factors (Kotler \& Armstrong, 2018; Kotler \& Keller, 2016). Two factors were eliminated because they did not meet the data analysis requirements and were stated not to shape the behavior of consumers of food service start-up businesses, namely cultural and social factors. After eliminating the two factors, the results of data analysis show that personal and psychological factors are factors that shape the behavior of consumers of food service start-up businesses.

\section{Personal Factors}

The results of data analysis show that personal factors shape consumer behavior. Based on research by Nafali \& Soepeno (2016), personal factors shape consumer behavior. Personal factors have three indicators namely age and stage of life, work and economic conditions, as well as personality and self-concept. The average consumer of a catering service start-up business is those aged $<20-25$ years and not married. This means they are going through life stages as teenagers who go to school or study. Kotler \& Keller (2016) says that a person will go through life stages that change according to his age. These changes in age and life stages create different needs and eventually form behaviors that change according to need.

The average consumer of a catering service start-up business is students who have not worked with an average consumption expenditure of Rp 1-3 million/month. Kotler \& Armstrong (2018) said that work and economic conditions shape consumer behavior based on the ability of consumers to buy a product based on income and expenditure. The consumers of the catering service start-up business are dominated by women. Kotler \& Keller (2016) said that consumers usually choose products that match their personalities. Most of the consumers of food service start-up businesses are women. This relates to a person's personality based on gender that affects the response to a product. Women's responses to catering products are better than men's responses. Personality is a distinguishing characteristic of women and men who show responses to several product and brand choices (Sunarto, 2018). Of course the dominance of catering consumers is women, this leads to women's responses to catering products better than men's responses.

\section{Psychological Factors}

The results of data analysis show that psychological factors shape consumer behavior. Psy- 
Finolda, Metta Padmalia / The Analysis of Consumers' Purchasing Factors on Boga Service Start-Up /

JEE, Vol. 8, No. 1, March 2019, pp. 25-32

chological factors shape beliefs. Meanwhile, attitudes shape the image of the product, consumers act on that image (Nofri \& Hafifah, 2018). Psychological factors have four indicators namely motivation, perception, learning, and memory. Customers of catering service start-up businesses are motivated to buy catering service start-up businesses to meet their needs when hungry. Solomon (2018) motivation grows from need. From the existence of these needs someone is encouraged to take action to meet the needs.

Customers of catering service start-up businesses have a perception that the catering service start-up business product is the most suitable product to answer needs. Kotler \& Armstrong (2018) say perception is the process of people sorting out information to form images according to their desires. Everyone buys the product that is most thought to answer their desires. Customers of food service start-up businesses have an understanding that buying catering can help meet dining needs. Kotler \& Armstrong (2018) said that consumer behavior can change after learning from experience. Customers of catering service start-up businesses have memories of knowledge about products that they think fits their needs. Kotler \& Keller (2016) say that memories are built based on what consumers know, memories collected form product knowledge

\section{CONCLUSION}

This study concludes that the factors of consumer behavior that shape the buying behavior of consumers of business catering for catering services are personal factors (X3) and psychological factors (X4). This personal factor means that consumer purchases are formed from the age $\&$ stage of life, work $\&$ economic conditions, personalities \& life concepts of each different consumer. Psychological factors this means psychological factors shape consumer behavior through motivation, perception, learning, and memories possessed by consumers. The results of the data processing show that consumer behavior factors in the purchase of catering business start-up services are ranked from the highest psychological factors (X4) and personal factors (X3).

Food service start-up businesses must ascertain whether the existing STPs are in accordance with customer characteristics. Food service start-up businesses must be able to shape good brand image perception through advertising, product appearance, packaging, and services. Business start-up catering services need to strive to hold promotions that interest consumers such as discounts, discounts, free delivery and bonuses. Food service start-up businesses need to conduct an evaluation to find out whether consumers' needs have been met by buying catering products.

\section{REFERENCES}

Ghozali, L. \& Latan, H. 2015. Partial Least Squares Konsep, Teknik, dan Aplikasi Menggunakan Program SmartPLS 3.0. Semarang: Universitas Diponegoro.

Hair, J.F., Black, W., Babin, B.J., \& Andreson, R.E. 2014. Multivariate Data Analysis. Englewood Cliffs, N.J.: Pearson Prentice Hall.

Indrawan, R. \& Yaniawati, P. 2017. Metodologi Penelitian Kuantitatif, Kualitatif, dan Campuran untuk Manajemen, Pembangunan, dan Pendidikan. Bandung: Refika Aditama.

Kemenperin.go.id. (t.thn.). Dipetik 10 11, 2018, dari Kemenperin: http://www.kemenperin. 
go.id/artikel/19543/Kinerja-Industri-Manufaktur-Masih-Positif-di-Triwulan-II-2018.

Kotler, P. \& Amstrong, G. 2018. Principles of Marketing. Englewood Cliffs, N.J.: Pearson Prentice Hall.

Kotler, P. \& Keller, K.L. 2016. Marketing Management. Englewood Cliffs, N.J.: Pearson Prentice Hall.

Nafali, M. \& Soepeno, D. 2016. Analisis Pengaruh Faktor-Faktor Perilaku Konsumen Terhadap Keputusan Pembelian Makanan Mie Instan merek Indomie. Jurnal EMBA, 4(4), 984-992.

Nofri, O. \& Hafifah, A. 2018. Analisis Perilaku Konsumen dalam Melakukan Online Shopping di Kota Makassar. Jurnal Manajemen, Ide, Inspirasi (MINDS), 5(1), 113-132.

Peter, J.P. \& Olson, J.C. 2009. Perilaku Konsumen \& Strategi Pemasaran (Buku 2, Edisi 9). Terjemahan Diah Tantri Dwandani. 2014. Jakarta: Salemba Empat.
Sangadji, E.M. \& Sopiah. 2013. Perilaku Konsumen. Yogyakarta: Andi.

Solomon, M.R. 2018. Consumer Behavior. Upper Saddle River,N.J.: Pearson Prentice Hall.

Sunarto. 2018. Analisis Perilaku Konsumen Terhadap Keputusan Pembelian Handphone Xiaomi Redmi 3S. Jurnal Moneter, 5(1), $35-43$.

Suprayitno, A., Rochaeni, S., \& Purnomowati, R. 2015. Pengaruh Faktor Budaya, Sosial, Pribadi, dan Psikologi Konsumen terhadap Keputusan Pembelian pada Bisnis Restoran Gado-Gado Boplo. Jurnal Agribisnis, 9(2), 177-214.

Wibowo, F.S. \& Bachtiart, Y. 2018. Analisa Kepuasan Konsumen terhadap Produk Katering di Ibu Djoko Catering. Jurnal Sains Terapan Pariwisata, 3(2), 253-268. 
Finolda, Metta Padmalia / The Analysis of Consumers' Purchasing Factors on Boga Service Start-Up / JEE, Vol. 8, No. 1, March 2019, pp. 25-32 